\title{
A Research on Improving Effectiveness of English Class in Middle School
}

\author{
Hui He \\ School of Foreign Languages, Zhengzhou University of Industrial Technology, Zhengzhou 451100, \\ China.
}

1456108581@qq.com

Keywords: English teaching strategy, teaching efficiency, teaching problems, innovation teaching.

\begin{abstract}
With the implementation of the new curriculum, higher requirements were put forward for English class teaching in middle school. Many English teachers have made a lot of efforts to explore a variety of English teaching methods in middle school. However, the general situation of English teaching in middle school is unsatisfactory. In order to be of great help for the English learners in middle school to find the correct ways to learn English, the author proposes three innovation teaching methods. All in all, English learning in middle school is critical to further study. So it is extremely necessary to do research on the effective learning ways for these English learners in middle school. This thesis provides a reference basis for the study of middle school English teaching and learning in future.
\end{abstract}

\section{Introduction}

\subsection{Research Background}

In China, the majority of children come into contact with English when they are in elementary school or even earlier. But their main stage to learn English is in middle school. Learning English in middle school plays a linking role between primary school and high school, which is also the accumulation stage for a variety of English learning in the future. English teachers encourage students to speak English more and use it creatively by presenting examples themselves. Although with the help of the teachers some students can master certain knowledge of English, not all students think that it is a good teaching method for them to learn English. And students often do not know how to accurately express their thoughts when English is applied in real or oral communication. Students can only speak simple sentences, which is far less than the expected English teaching objective. The most fundamental reason of this situation lies in middle school class teaching.

Confucius, the pioneer of Confucianism, who said, teacher should not enlighten their students until they themselves have done serious thinking about the problem in their mind and achieved some thoughts, however, they cannot express it in words, which is Confucius's famous words on common teaching. While in present education, it refers that effective classroom teaching is to create the best opportunity for the students to learn. Many English teachers in middle school spare no effort to explore a variety of English class teaching strategies to change this phenomenon. However, the overall situation of English teaching is not ideal.

\subsection{Theoretical Foundation}

This thesis is based on Jean Piaget' Cognitive Development Theory. The Swiss psychologist Jean Piaget studied process, characteristics and the regulation of the thinking occurrence, development. To him, the new knowledge came from successive formation. And he thought that the process of cognition includes two kinds of functions, assimilation and accommodation.

Assimilation refers that a person brings the cognition object into the subject cognition structure, namely, a cognitive formation. The conformance is that the subject cognition structure can't assimilate the unknown object, which causes qualitative changes of the cognitive structure, and helps the person adjust the original cognitive structure or establish a new one, which is accommodation. This is the cognitive improvement. Piaget discovered that man's knowledge acquirement during the 
period from childhood to adult is not a simple single activity, but a bimodal activity of assimilation and accommodation, and thus a new cognition about the object comes into existence. It seems that the object can make the relevant reaction only when a certain stimulus is assimilated into cognition structure, the process can be simply expressed.

Piaget's discovery of psychology provides scientific theory basis for changing traditional infusion teaching method, setting up a student-centered and interest-centered method and presenting lead-in among a lively and easy classroom atmosphere. As we all know, education cannot be separated from psychology. Students in middle school are in adolescence when one is liable to show his or her personality, to revolt against his or her teachers. As students' mood swings greatly in such a special time, classroom teaching is more than a process of knowledge imparting. Teachers should not only possess foundation of relevant knowledge but also know clearly students' inner world.

Therefore, during English class, the new contents to be learned should be tactfully designed by means to stir up students' eager to acquire more new knowledge and their satisfaction of achievement, which is the key to leading in the new lesson successfully.

\subsection{Research Significance}

Classroom teaching is the only way for most students to learn English as a second language. At present, most teachers have realized that the application of effective classroom English teaching strategies at the starting point of a class can create a relaxing and delightful atmosphere and then help middle school students cultivate an active learning spirit. In this way, middle school students may improve their English learning quality and efficiency greatly.

This thesis explores creative English teaching strategies in middle school through the study on the present status of English teaching issues. The purpose of this thesis is to deepen people's understanding of English teaching and to update the traditional concept of education for English teaching. And this thesis provides the basis for the development and improvement of English teaching and also the theoretical selection and guidance to improve English teaching in middle school. English learning in middle school as a basis for future learning is imperative. This thesis can help the students to lay a solid English foundation in middle school. Therefore, students' abilities of listening, speaking, reading, writing, translating are all improved for the further English learning. What's more, students who just start to learn English can cultivate a good study habit of accommodating the new curriculum.

As newer and higher requirements for English teaching have been put forward, it is necessary to train people to meet the new requirements and new needs of society and also necessary to promote English teaching to continue to carry out reforms and move forward.

\section{Problems of English Class Teaching in Middle School}

\subsection{English Teaching Situation in Middle School}

For a long time, China focuses on elementary training in English teaching, which causes a fixed pattern of "Teacher Centers, Teaching Centers and Classroom Centers". Classroom English teaching is an energy field, which is a place full of excitement and amazement. But this sort of power does not happen all by itself; rather, it depends on the teachers' thoughtful teaching. But most of time the teacher on the platform is always in full flight, but the students are always sleepy with a passive acceptance of knowledge as the audience, which causes that students' learning results are not ideal. At home and abroad, English teaching in middle school has its own advantages and disadvantages. What are the advantages and disadvantages of English teaching in China? Therefore, English teaching situation will be introduced as following.

During the past two decades, English teaching in middle school has made great progress in the following aspects. First, the government has developed a series of education policies in favor of English teaching, such as all kinds of foreign language education training objectives. Second, recently the educational office has established unified national curriculum and launched a new textbook published with the assistance of British in middle school. Third, the whole society has a clear understanding of the importance of learning English and works together to create a good atmosphere 
for English learning. However, disadvantages come after the progress. There is a common mode in Chinese classroom English teaching, which derived from the former Soviet Union Kairov "Reviewing old knowledge - Teaching new knowledge — The consolidation of new knowledge Homework". This fixed English teaching pattern has been dominant in our country for a long time, so teacher is the controller. The teacher is continuously talking and talking on the platform, while students are crazily writing down notes on their textbooks. Teachers always start to present the key points from the beginning till the bell rings. There has been appeared a passive acceptance when students are learning English, because the students are in strict accordance with the teachers' requirements.

With the progress of China's society and the development of science and technology, this teacher-centered teaching has exposed its drawbacks. Under the background of examination-oriented education, it has caused an examination heat because all teaching activities serve for testing under the pressure of entrance examination. What has been mentioned above has virtually narrowing the English teaching mode to "test" teaching mode.

\subsection{Good English Teaching Cases from Foreign Countries}

In Canada, Immersion Approach is very popular among students and teachers. The students immerse in the target language environment. In teaching activities, teachers not only give a lecture with the target language, but also with the purpose language to teach other courses. McGill University researchers gave students a professional language level test and they compared the language skills, creativity, intelligence level, etc. between the students who had accepted Immersion Teaching Method with those who had not. The results proved that students who accepted Immersion Teaching Method would be able to listen to relatively, speak fluently and be good at reading and writing in English in middle school.

Singapore attaches great importance to the creation of a bilingual educational environment, whether at classrooms, laboratories, libraries, or at corridors, halls and other venues. Bilingual marks are everywhere. Students accept bilingual information anytime, anywhere. In addition to the school environment, Singapore's social bilingual education environment is also a major feature. Bilingual programs provide bilingual information by radio and television, newspapers and magazines. And on the streets, in the shopping malls, at railway stations and airports, in zoos, birds museum, and science museum, everywhere reflects a bilingual atmosphere.

Look at the Canadian English teaching in middle school from the teacher Jennifer's classroom. When she introduces Canadian culture, the common method used by Jennifer is first to play a video related to Canada, and then ask the students to recall any of the information in the video and write on the blackboard. Finally, allow students to imitate sample to make some valuable dialogues. At the beginning, students find it difficult to adjust but after three days of teaching, students are able to adapt to these teaching activities and they can summarize the main idea very well. Furthermore, a lot of games are included in classroom activities, such as Hangman Game, Bingo, Killer Game, Words Whisper and so on. Students will learn English language unconsciously while they do their best to finish these games.

\subsection{Teaching Insufficiency in Middle School}

Comparing the way of English teaching in middle school between domestic and foreign countries, insufficiency will be found in English teaching status in our country.

The traditional model of English teaching ignores the dominant position of students. A famous saying goes like this, "It is to learn a foreign language, not to teach." So how the teachers arrange the main role of students and inspire students to learn a foreign language is particularly important. First is to make students willing to learn, the second is to teach students how to learn, because these are the best ways to achieve good results.

In China, students' English learning lacks of natural language environment, which is the main obstacle for English learners. Students rely mainly on foreign language class and they listen more, read more and practice more in a mechanical way. As a result, the language which students learned is not wholly true nature of English, but a hybridity and Chinglish. As former Deputy Prime Minister Li 
described, "Many students learn English for more than 8 or 12 years but cannot read the original book skillfully, cannot understand and even cannot speak. And it is difficult for them to directly communicate with foreigners." English is a universal language in the international society and many countries take it as the first foreign language in school. After 1960s, English is the common language of international communication and it is also an important tool for the language of the information age.

With the strategic adjustment of the economic structure and improvement of China's socialist market economic system, current situation of English teaching in middle school has been unable to adapt to the new quality standards proposed by society for English talents. Effective teaching innovation strategies should come out to develop excellent English talents, especially for the English class teaching in middle school.

\section{Strategies for Innovative Class Teaching in Middle School}

\subsection{Situational Teaching Strategy}

Social environment is crucial for language learning. The baby's language acquisition is familiar with the results of subtle, and not through specialized formal training. Immersion teaching practice is also the further evidence. Because it is necessary to produce the "soil" and require language learning environment for learning a foreign language, so it is very essential to create a suitable English learning atmosphere.

Generally speaking, teachers should start with the following aspects. Firstly, decorate the English classroom with some pictures about western famous buildings, or landscapes to create an atmosphere for the students. Staying in a foreign country, students are likely to communicate with others in English. Secondly, as for learning environment, we can learn a lot from Singapore's bilingual education. Teachers should make full use of a variety of teaching methods, from the traditional ones as teaching charts, small blackboard to the modern teaching tools like slide, video, multimedia, etc. These methods can be all used as a means of creating a foreign language learning environment. So that whenever and wherever students are, they can often listen to English, speak English, and cultivate themselves to think or express in English.

In fact, creating scenes is the essence of situational teaching strategy, and middle school students are interested in scenes. For instance, teachers use pictures to create a scene of "visual demonstration scene". And the focus must be on the proportion and color of the important people or event, but the background should not be conspicuous. The line drawings make students focus on essential content and enhance the teaching interesting. For instance, when teachers teach "upstairs and downstairs", they can draw some pictures on the blackboard. When teachers teach the word "orange", they can bring some oranges into class but not one. By such kind of means, the class can become more interesting. Therefore, creating scenes is the best advantage of the situational teaching method which can stimulate students' interest. Situational teaching method can motivate students to learn English. Stimulating middle school students' interest in learning is one of the important functions and purposes of the situational teaching method. Raising students' interest is a premise for teaching. It can make middle school students concentrate on their study, and have enthusiasm, pleasant emotional experience for English learning. Teachers should be enthusiasm to teaching activities with superb teaching art to create an attractive teaching scene in English class. For example, in teaching sentences: I think so. / I don't agree. Teachers can combine the knowledge with what students are interested in. In details, teachers may take the famous stars or singers for example.

T: I think Xiao Yanzi is very beautiful. She has big eyes. Do you think so?

S: No. I don't agree. I don't think she is beautiful. But I think she is lovely.

T: Do you think she is a good actor?

S: Yes, I agree.

T: Do you think Cheng Long is a good singer?

S: Yes, I agree. And I think he is also a good actor. 
The situational teaching strategy can arouse middle school students' interests in class, because the situational teaching should be more suitable for middle school students' age, psychological characteristics. On such kind occasion, students can freely talk with others in English. Eventually, teaching in classroom has to be closely coordination with the scenes, and students should be put into the certain situation. Moreover, students should have a close contact with the thing that a certain situation involved.

\subsection{Group Incentive Strategy}

American educator Bloom believes that the group learning programs can be very effective when it converts to a cooperative learning process and everyone will benefit. Language learning in particular needs to communicate with others. In English class, teachers can provide students with text play acting, sketch acting and dialogue acting according to the contents of texts and their English levels. By working in groups of four or three and helping each other and cooperating with each other, the students can feel at ease while speaking English and they will become to enjoy speaking English. The value of cooperative learning among these groups is as follows.

On the one hand, this teaching strategy is suitable for all the students. Excellent students can make great progress because of helping others to improve their English skills. They also act as a teacher's assistant to guide the weak students. On the other hand, the team can compete with each other and work together to promote learning, thereby to enhance the students' motivation to learn. What's more, not only in the classroom, but also out of the classroom groups can check each other's homework. This teaching method can inspire each other and help them make progress together to develop the spirit of collaboration among the students. During this process, teachers can ask students to comment on their performance and what they have learned from the others so as to improve themselves. At last, the teacher should make summary on the aspects where the learners have done well and where they need to work harder to improve.

Group incentive strategy can draw students' attention. Foreign language teaching can make students consistently remain attention. To make students focus on the study, teachers cannot rely on orders and requirements, but depend on the scientific and artistic of teaching activities. Naturally students can be attracted by the contents. When teaching colors, teachers can divide the class into three or four teams and use the classroom and various items of clothing, shoes, and hats. For example:

$\mathrm{T}$ : What color is the chalk (blackboard, door, desk etc.)?

S: It's white (black, blue, orange etc.).

$\mathrm{T}$ : What color is his coat (sweater, pencil-box, bag etc.)?

S: It's yellow (red, green, gray, white etc.).

$\mathrm{T}$ : What color are the flower (your desks, his trousers, her shoes etc.)?

S: They are red (pink, black, brown etc.).

As we all know, students in middle school are all teenagers who are always aggressive and unconvinced. According to their character, students can concentrate on English learning in such a game. And students could understand natural and authentic meanings, and the English teaching procedure may become very vivid.

\subsection{Extracurricular Activity Strategy}

Activities are incentives for middle school students to work hard and also chances for them to get feelings of success. One of teachers' jobs is to ensure students a variety of activities. By presenting students with a variety of activities teachers can ensure their continuing interest in the language learning program. Classes which continually have the same activities are not likely to sustain interest, particularly where the students have no extrinsic motivation and do not perceive clear long-term goals. A program, however, that presents a variety is far more likely continually to engage the students' interest. Through English activities, middle school students can have more chances to speak English as well as use English in the artificial English surroundings. They can have more chances to get feelings of success. Accomplishment is the assurance of their progress in their English study.

As an old saying goes, "Practice makes perfect", which is also useful in English teaching. In English learning, a mere 45 minutes in class is not enough. It is a progressive and repeatable process 
in accumulation of language acquisition, verbal ability as well as communication ability. English will be obtained and sublimated in constant use and practice. Therefore activities should be flexible. Outside class, English corner, reading competition, English songs competition and English party etc. are all good activities which always attract the students and impel them to speak more English. And debates relevant to hot issues in the world seem to be the most popular activities. Teachers can organize the students to argue about some current affairs, which links what they have learned with practice and helps them to express their real thoughts. In a word, all activities are determined by teachers. So teachers' ability should be both adaptable and flexible. For example, make a simple dialogue about buying tickets. Students can play a variety of roles, and repeat to use various words and sentences.

T: Good afternoon, Sir. What can I do for you?

S: I'd like to go to Shang Hai. May I have a ticket, please?

T: Ok. Wait a moment, please.

S: Ok. Thank you.

(A few seconds later...)

T: Here is your ticket. Would you want to pay by cash or card?

S: Cash.

T: This is your change, here you are.

S: Thank you very much. Goodbye.

T: You are welcome. Have a nice day! Bye bye.

The form of this dialogue is very close to life. It's easy for students to practice. Interesting classroom is full of extra-curricular activities, such as games, dramas and other forms of activities. What truly arouse the initiative of students and extend the classroom teaching content are the extra-curricular activities, so regular extracurricular activities should be hold on time to supply a platform for students to exercise themselves and give them a chance to make performance in their oral English. Apart from these, the comments on the student's performance will also make students have more confidence in English learning.

\section{Significance of Innovative Class Teaching in Middle School}

\subsection{To Stimulate Students in Learning}

Under the new curriculum standards, the basic idea of stimulating students' interest in learning is "to develop student-centered," and to "advocate self-inquiry approach to learn." It is to give every student the full potential in the learning process to take the initiative to explore and discover new knowledge, so as to achieve purpose of "teaching is not to teach". Therefore, teachers should create situations for students to stimulate students' interest in active learning.

Significance of creating teaching atmosphere is that it can inspire students to actively explore the knowledge, which is a strategy commonly used to teach. As an old saying goes, "Learning from thinking, and thinking from questioning." Students tend to start with problems to explore the desire for knowledge and get the joy of success in the process of problem solving. Teachers should be good at creating situations to stimulate students to actively search for knowledge. And the teachers desire to make the process of English teaching have an invisible attraction for their students to acquire knowledge actively. Thus, the creation of teaching circumstances is to stimulate students' interests in active participation in learning.

Bruner once said, "The best motivation to learn is that the students' inner interest is in what they have learned the material itself has." Therefore, teachers should strive to create workable context for students to practice, to experience the joy of learning English and to stimulate student's interests in actively learning English. What's more, it is an effective way to improve the efficiency of classroom teaching and an effective means of cultivating students' interests in learning. 


\subsection{To Motivate Students' Ambition}

English learning motivation includes three parts, attitude, desire and effort. Motivation is seen by foreign language educators as the most important issue when facing the actual condition teaching. Teenagers are always willing to do what they think is interesting or funny instead of necessity of doing so. They are not mature in thinking, and their mood is always swinging badly. It is the teachers' job to stir up students' motivation to learn, which is more necessary than teaching itself. Psychologists find that students in middle school are in a feisty stage. Competition is a very effective means to inspire students' positive attitude and to gain the upper hand in the psychological external manifestations. So in English class, competition enables students to compete with each other initiatively to learn from each other, to catch up with each other.

For example, the teacher can divide the class into four groups when checking words. The group, which has written the less correct words, will be punished. The students themselves in order to be unpunished will actively prepare in advance. Another example is students in one group will check each other's assignment and recommend one who has done the best to be the group leader. Then with great honor this leader are going to check the group members' homework next time. In this way, you will find students' pre-class preparation is particularly abundant because they all want to check others' assignment. Grouping method can excite students' divergent thinking and enhance students' self-confidence. If teachers use grouping incentives appropriately, students will be able to achieve satisfactory learning results.

\subsection{To Create Learning Atmosphere}

Learning atmosphere is very important for students. Favorable environment makes students have a positive attitude towards learning. In ancient times, Mencius' mother moved three times to provide a better education environment for him. This story illustrates the importance of creating a good learning atmosphere for students, especially for English learning, because English is not our mother tongue.

Good atmosphere is a precondition in English learning and only in good English learning atmosphere, students can enjoy learning. Firstly, in English class, teachers can encourage students to read more small essays, newspapers or to watch cartoons in English, so that students will become familiar with the frequently used sentences. Secondly, listening and speaking occupy very important positions in English learning. It is useless if they can only understand but cannot express themselves. Therefore, during class, teachers should find ways to create a good atmosphere for students to listen and to speak. Allow students to listen to more broadcast and imitate pure English pronunciation. Students are encouraged to talk with teachers and their classmates in English to improve their listening and speaking to the maximum extent. Thirdly, school should host English speech, English songs and other activities regularly. And teachers should encourage all students to actively participate in these activities.

Only with students being involved in success, happiness and joy from English learning, can they be more active in the future study and more enthusiastic about English class.

\section{Conclusion}

This thesis is based on the present status of English teaching in middle school. A general teaching situation in middle school is analyzed and also compared with good teaching cases from foreign countries, from which it can be seen that there are some teaching insufficiency in our country in middle school English teaching and we should learn creative teaching methods from the other countries. Although this phenomena has been greatly changed, English teaching problems in middle school still need to be solved.

There are three innovative strategies which are to stimulate students' interests, to motivate students' ambition and to create learning atmosphere. These strategies are introduced to refine our English teaching in middle school to help students acquire knowledge and develop good study habits in English learning. Despite the current situation is not ideal, we should firmly believe that English teaching reform in middle school will achieve the ideal results. 
Because of the limited time, personal knowledge and the other reasons, this thesis has many deficiencies. I sincerely expect your opinions.

\section{References}

[1]. Gingras, R. Second Language Acquisition and Foreign Language Teaching Wash [M]. Shanghai: Shanghai Educational Press, 2006.

[2]. Grice. Studies in the Way of Words [M]. New York: Longman, 2008.

[3]. George. Towards English Teaching [M]. New York: Random House, 2007.

[4]. Le Jia. "FPA Four Personality Analysis" [D]. HuNan: WenYi Press,2012(71).

[5]. Liu Runqing. Self-collections in English Teaching [M]. BeiJing: Foreign Language Teaching and Research Press, 2007.

[6]. Qi Hong, Lin Na. "English Teaching in the 21st Century" [J]. HaiNan: Journal of Northwest University, 2009(04).

[7]. Zhou Xiaopei. "How to Teach English Well in Middle School” [J]. ShangHai: Teaching Press, 2009(10). 